\title{
PEMBUATAN DAN PEMANFAATAN ARANG AKTIF SEBAGAI REDUKTOR EMISI FORMALDEHIDA KAYU LAPIS
}

\section{(Manufacturing and Application of Activated Charcoal as Reductor of Plywood Formaldebyde Emission)}

\author{
Oleh/By : \\ Gustan Pari, Adi Santoso \& Djeni Hendra ${ }^{1)}$
}

\begin{abstract}
The research was conducted to evaluate production of activated charcoal from Acacia mangium Willd saw dust as reductor for formaldebyde emission on plywood adhesive. Sawdust was carbonized at temperature $500^{\circ} \mathrm{C}$ prior to charcoal manufacturing. Production process of activated charcoal was conducted in a retort constructed from non-corrosive steel that fitted with electric heater. Charcoal were activated with chemical, physical and combination between chemical and physical treatments.

The results indicated that good quality of activated charcoal using combination process of oxidation and chemical treatment. At this condition, the yield of activated charcoal was $53.00 \%$, with contents of moisture, ash, volatile matter and fixed carbon respectively 4.33, 8.17, 5.88 and $83.77 \%$. Adsorptive capacity againts ben₹ene, chloroform, iodine, methylene blue and formaldehyde was $14.59 \%, 28.96 \%, 960.23 \mathrm{mg} / \mathrm{g}, 135.0 \mathrm{mg} / \mathrm{g}$ and $26.21 \%$ respectively.

Activated charcoal used as catching agent on plywood adhesive was able to decrease formaldehyde emission from plywood taper. Formaldehyde emission from conventional plywood was 16.48 ppm, higher than those added with the activated charcoal (15.35 ppm) without significant affect to its bonding strength.
\end{abstract}

Keywords: Active charcoal, saw dust, mangium, plywood, formaldehyde emission.

\begin{abstract}
ABSTRAK
Telah dilakukan penelitian pembuatan arang aktif dari serbuk gergajian kayu Acacia mangium Willd. Arang aktif yang dihasilkan digunakan sebagai reduktor emisi formaldehida pada perekat kayu lapis. Tujuan penelitian ini adalah untuk memanfaatkan limbah serbuk gergajian kayu mangium untuk dibuat arang aktif dan digunakan sebagai reduktor emisi formaldehida dalam perekat kayu lapis. Sebelum dibuat arang aktif, serbuk gergajian diarangkan dalam pada suhu $500^{\circ} \mathrm{C}$. Arang yang dihasilkan diaktivasi secara kimia, fisika dan kombinasinya di dalam tungku baja tahan karat yang dilengkapi dengan pemanas listrik.

Hasil penelitian menunjukkan bahwa kualitas arang aktif yang terbaik diperoleh dari serbuk gergajian kayu mangium yang diaktivasi dengan cara kombinasi oksidasi gas dan kimia dengan
\end{abstract}

${ }^{1}$ Peneliti pada Pusat Penelitian dan Pengembangan Hasil Hutan, Bogor 
rendemen sebesar 53\%, kadar air 4,33\%, kadar abu 8,17\%, kadar zat terbang 5,88\%, kadar karbon terikat $83,77 \%$, daya serap terhadap yodium sebesar $960,2 \mathrm{mg} / \mathrm{g}$, metilien biru 135,0 mg/g, benzena $14,59 \%$, kloroform $28,96 \%$ dan daya serap terhadap formaldehida sebesar $26,21 \%$.

Pencampuran arang aktif pada perekat kayu lapis mampu menurunkan emisi formaldehida pada perekat kayu lapis. Terbukti dari hasil uji emisi kayu lapis tanpa penambahan arang aktif menunjukkan emisi formaldehida sebesar 16,48 ppm, sedang emisi yang dihasilkan dengan penambahan arang aktif sebanyak 5\% menurun menjadi 15,36 ppm, tanpa mempengaruhi ketegutan rekat kayu lapis.

Kata kunci: Arang aktif, serbuk gergaji kayu, mangium, kayu lapis, emisi formaldehida

\section{PENDAHULUAN}

Arang aktif adalah arang yang diaktivasi dengan cara kimia atau fisika sehingga daya serapnya tinggi dengan kadar karbon yang bervariasi. Permukaan arang aktif relatif telah bebas dari deposit hidrokarbon dan mampu melakukan adsorpsi karena permukaannya lebih luas dan pori-porinya telah terbuka (Baker, et al., 1997).

Unsur karbon (C) pada arang aktif mampu menyerap anion, kation, dan molekul dalam bentuk senyawa organik maupun anorganik, baik sebagai larutan maupun sebagai gas. Hal ini dikarenakan atom karbon tersebut terikat secara kovalen dalam suatu kisi heksagonal yang mirip dengan grafit. Pelat-pelat ini terkumpul satu sama lain membentuk kristal dengan susunan tidak beraturan (amorf), dengan jarak antar pelatnya acak (Solovyov, et al., 2002). Perkembangan terakhir di jepang menunjukkan bahwa arang aktif dari kayu dapat menyerap uap formaldehida yang berasal dari formalin (Asano, et al., 1999). Atas dasar ini arang aktif yang dibuat dari serbuk kayu Acacia mangium akan digunakan sebagai bahan penangkap gas formaldehida yang diemisikan dari kayu lapis, sekaligus berfungsi sebagai bahan pengisi guna mengurangi pemakaian perekat murni dan mengatur kekentalan ramuan perekat.

\section{BAHAN DAN METODE}

\section{A. Bahan}

Bahan baku yang digunakan dalam penelitian ini adalah serbuk gergajian kayu mangium yang berasal dari Jawa Barat. Bahan kimia yang digunakan di antaranya adalah yodium dan metilen biru untuk penetapan daya serap arang aktif terhadap larutan. Kloroform, benzena, dan formalin untuk penetapan besarnya daya serap arang aktif terhadap gas.

\section{B. Metode}

Sebelum dibuat arang aktif, serbuk gergaji kayu mangium dikarbonisasi pada suhu $500^{\circ} \mathrm{C}$ selama 5 jam di dalam tungku kapasitas 3,0 kg dengan pemanas listrik. Sedangkan proses pembuatan arang aktif dilakukan di dalam tungku kapasitas $0,5 \mathrm{~kg}$ yang terbuat dari baja tahan karat dan dilengkapi dengan elemen listrik sebagai pemanas serta termokopel. Proses aktivasi yang dilakukan adalah cara kimia yaitu perendaman arang dalam larutan $\mathrm{H}_{3} \mathrm{PO}_{4}$ 5\% selama 24 
jam (a1), aktivasi cara fisika yaitu mengalirkan uap air ke dalam tungku (a2) dan kombinasi cara kimia dan fisika, arang direndam $\mathrm{H}_{3} \mathrm{PO}_{4} 5 \%$ dan dialirkan uap air (a3) serta perlakuan panas/tanpa uap air dan bahan kimia (a4). Bahan baku serbuk gergaji kayu mangium dimasukkan ke dalam tungku, kemudian suhu dinaikkan secara bertahap sampai mencapai $800^{\circ} \mathrm{C}$ yang selanjutnya arang serbuk kayu mangium diaktivasi sesuai dengan perlakuan di atas. Arang aktif yang dihasilkan ditetapkan rendemen dan diuji kualitasnya menurut cara uji arang aktif yang ditetapkan SNI (Anonim, 1995) yang meliputi penetapan kadar air, abu, zat terbang, karbon terikat, daya serap terhadap yodium, dan metilen biru. Untuk mengetahui tingkat kepolaran arang aktif, dilakukan pengujian daya serap masing-masing terhadap benzena, kloroform, dan formaldehida.

Arang aktif yang dihasilkan diaplikasikan pada perekat kayu lapis dengan cara membuat venir dari kayu afrika (Maesopsis manii) ukuran 40 x $40 \mathrm{~cm}$, tebal 1,5 mm. Pembuatan kayu lapis berupa tripleks menggunakan perekat urea formaldehi-da dengan bobot labur $170 \mathrm{~g} / \mathrm{m}^{2}$ tiap permukaan. Pengeras yang digunakan adalah $\mathrm{NH}_{4} \mathrm{Cl}$ 0,5\% dari perekat cair dan bahan pengisinya arang aktif hasil penelitian sebanyak $5 \%$ dari berat perekat urea formaldehida. Setelah pelaburan perekat pada kayu lapis, dilakukan pengempaan panas pada kayu lapis selama 3 menit, pada suhu $110^{\circ} \mathrm{C}$ dengan tekanan $15 \mathrm{~kg} / \mathrm{cm}^{2}$. Kualitas kayu lapis yang di uji meliputi penetapan kadar air, kerapatan dan keteguhan rekat kayu lapis dilakukan berdasarkan SNI (Anonim, 1992). Penetapan emisi formaldehida dilakukan berdasarkan standar Jepang (Anonim, 1982).

\section{HASIL DAN PEMBAHASAN}

\section{A. Rendemen dan Kualitas Arang Aktif}

\section{Rendemen arang aktif}

Pada Tabel 1 terlihat bahwa rendemen arang aktif berkisar antara 46,2581,5\%. Dari hasil uji sidik ragam (Tabel 2) ternyata cara aktivasi sangat mempengaruhi rendemen arang aktif yang dihasilkan. Rendemen tertinggi terdapat pada arang serbuk gergajian $A$. mangium yang diaktivasi dengan cara dipanaskan, tanpa diberi aktivasi cara kimia maupun fisika. Sedangkan rendemen yang terendah terdapat pada arang serbuk gergajian $A$. mangium yang diaktivasi dengan cara oksidasi. Rendahnya rendemen arang aktif ini dapat diterangkan berdasarkan reaksi sebagai berikut:

$$
\begin{aligned}
\mathrm{C}+\mathrm{H}_{2} \mathrm{O} & \rightleftharpoons \mathrm{C}\left(\mathrm{H}_{2} \mathrm{O}\right) \\
\mathrm{C}(\mathrm{HOH}) & \rightleftharpoons \mathrm{H}_{2}+\mathrm{C}(\mathrm{O}) \\
\mathrm{C}(\mathrm{O}) & \rightleftharpoons \mathrm{CO} \\
\mathrm{C}+\mathrm{H}_{2} & \rightleftharpoons \mathrm{C}\left(\mathrm{H}_{2}\right) \\
\mathrm{C}+\mathrm{H}_{2} \mathrm{O} & \rightleftharpoons \mathrm{C}(\mathrm{H})+\mathrm{C}(\mathrm{OH}) \\
\mathrm{C}(\mathrm{H})+\mathrm{C}(\mathrm{OH}) & \rightleftharpoons \mathrm{C}\left(\mathrm{H}_{2}\right)+\mathrm{C}(\mathrm{O}) \\
\mathrm{CO}+\mathrm{H}_{2} \mathrm{O} & \rightleftharpoons \mathrm{CO}_{2}+\mathrm{H}_{2} \\
\mathrm{CO}+\mathrm{C}(\mathrm{O}) & \rightleftharpoons \mathrm{CO}_{2}+\mathrm{C}
\end{aligned}
$$


Dari reaksi tersebut terlihat bahwa senyawa karbon yang terbentuk dari hasil penguraian selulosa dan lignin serbuk gergajian kayu mangium mengalami reaksi pemurnian dengan uap air sehingga senyawa non karbon yang melekat pada permukaan arang menjadi menguap. Namun demikian karena reaksi yang terjadi secara radikal maka atom C. yang terbentuk akan bereaksi kembali dengan atom $\mathrm{O}$ dan $\mathrm{H}$ membentuk $\mathrm{CO}, \mathrm{CO}_{2}, \mathrm{CH}_{4}$ sehingga rendemen arang aktif yang dihasilkan akan lebih rendah dibandingkan dengan arang aktif yang dibuat hanya dengan perlakuan panas.

Berdasarkan hasil uji-beda (Lampiran 1) diketahui bahwa semua perlakuan yang diberikan menghasilkan rendemen arang aktif yang berbeda nyata, dan untuk membuat arang aktif dengan rendemen tinggi diperlukan perlakuan panas.

Tabel 1. Sifat dan kualitas arang aktif serbuk gergajian kayu A. mangium Table 1. Properties and quality of activated charcoal from A. Mangium sawdust

\begin{tabular}{|l|r|r|r|r|r|}
\hline \multirow{2}{*}{ Sifat (Properties) } & \multicolumn{5}{|c|}{ Perlakuan (Treatment) } \\
\cline { 2 - 6 } & $\mathrm{a} 1$ & $\mathrm{a} 2$ & $\mathrm{a} 3$ & $\mathrm{a} 4$ & $\mathrm{a} 5$ \\
\hline A. Sifat (Properties) & & & & & \\
1. Rendemen (Yield), \% & 48,00 & 46,25 & 53,00 & 81,50 & - \\
2. Kadar air (Moisture content), \% & 2,89 & 3,28 & 4,33 & 3,25 & 21,83 \\
3. Kadar abu (Ash content), \% & 4,19 & 6,55 & 8,17 & 6,49 & 18,30 \\
4. Kadar zat terbang (Volatile matter), \% & 5,07 & 8,81 & 5,88 & 1,93 & 7,57 \\
5. Kadar karbon (Fixed carbon), \% & 89,29 & 83,01 & 83,77 & 89,94 & 81,47 \\
& & & & & \\
B. Kualitas (Quality) & & & & & \\
Daya serap (Adsorption capacity) : & & & & & \\
1. Yodium (Iodine), mg/g & 505,6 & 916,0 & 960,2 & 453,5 & 626,3 \\
2. Metilin biru (Metbyline blue), mg/g & 71,1 & 122,8 & 135,0 & 63,7 & 102,7 \\
3. Benzena (Benzene), \% & 9,20 & 15,28 & 14,59 & 9,08 & 19,15 \\
4. Kloroform (Chloroform), \% & 12,86 & 27,05 & 28,96 & 13,03 & 27,31 \\
5. Formaldehida (Formaldehyde), \% & 11,57 & 26,05 & 26,21 & 8,84 & 28,73 \\
\hline
\end{tabular}

Keterangan (Remarks): a1 = Perlakuan dengan bahan kimia (Chemical treatment), a2 = Perlakuan dengan fisika (Physical treatment), a3 = Perlakuan dengan bahan kimia dan uap air (Combination treatment of chemical andphysical), a4 $=$ Perlakuan dengan panas (Heat treatment), a5 = Arang aktif pasaran (Commercial activated charcoal)

\section{Kadar air}

Pada Tabel 1 terlihat bahwa kadar air arang aktif dari serbuk gergaji kayu A. mangium berkisar antara 2,89 - 4,33\%. Nilai ini memenuhi Standar Nasional Indonesia (Anonim, 1995) karena kurang dari 15\%. Berdasarkan hasil uji sidik ragam (Tabel 2) ternyata cara aktivasi sangat mempengaruhi kadar air arang aktif yang dihasilkan. Kadar air tertinggi (4,33\%) terdapat pada arang serbuk gergajian kayu $A$. mangium yang diaktivasi dengan cara kombinasi uap air dan bahan kimia. Sedangkan untuk kadar air yang terendah $(2,89 \%)$ terdapat pada arang serbuk gergajian kayu $A$. mangium yang diaktivasi dengan cara dipanaskan. Rendahnya 
kadar air ini menunjukkan bahwa kandungan air bebas dan air terikat yang terdapat dalam arang serbuk gergajian kayu $A$. mangium telah menguap selama proses karbonisasi. Sebaliknya untuk kadar air yang tinggi selain disebabkan oleh sifat higroskopis arang aktif, dan juga adanya molekul uap air yang terperangkap di dalam kisi-kisi heksagonal arang aktif terutama pada proses pendinginan.

Hasil uji-beda (Lampiran 1) menunjukkan bahwa tidak semua cara aktivasi memberikan perbedaan kadar air yang nyata, seperti arang serbuk gergajian kayu $A$. mangium yang diaktivasi dengan cara uap air sebesar 3,28\% tidak menyebabkan perbedaan kadar air yang nyata dengan arang serbuk gergaji $A$. mangium yang diaktivasi dengan cara dipanaskan yaitu sebesar 3,25\%. Untuk membuat arang aktif dengan kadar air yang baik adalah dengan cara kimia. Apabila dibandingkan dengan kadar air arang aktif yang berasal dari pasar sebesar 21,83\%, maka arang aktif hasil penelitian mutunya masih lebih baik (2,89 - 4,33\%).

\section{Kadar abu}

Pada Tabel 1 terlihat bahwa kadar abu arang aktif dari serbuk gergajian kayu $A$. mangium berkisar antara 4,19 - 8,17\%. Angka kadar abu ini memenuhi Standar Nasional Indonesia (Anonim, 1995) karena kadar abunya kurang dari 10\%. Berdasarkan hasil uji sidik ragam (Tabel 2) ternyata perlakuan cara aktivasi sangat mempengaruhi kadar abu arang aktif yang dihasilkan. Kadar abu tertinggi $(8,17 \%)$ terdapat pada arang serbuk gergajian kayu $A$. mangium yang diaktivasi dengan cara kombinasi antara uap air dan bahan kimia. Sedangkan untuk kadar abu yang terendah (4,19\%) terdapat pada arang serbuk gergajian kayu A. mangium yang diaktivasi dengan cara kimia. Rendahnya kadar abu ini menunjukkan bahwa telah terjadi reaksi pertukaraan ion antara gugus $\mathrm{OH}$ yang terdapat pada selulosa yang dikandung serbuk gergajian kayu $A$. mangium dengan $\mathrm{PO}_{4}$ yang berasal dari $\mathrm{H}_{3} \mathrm{PO}_{4}$ sehingga dapat menghambat proses oksidasi lebih lanjut.

Dari hasil uji-beda (Lampiran 1) menunjukkan bahwa tidak semua cara aktivasi menyebabkan perbedaan kadar abu yang dihasilkan, seperti arang serbuk gergajian kayu $A$. mangium yang diaktivasi dengan cara oksidasi sebesar 6,55\% tidak menyebabkan perbedaan dengan arang serbuk gergajian kayu $A$. mangium yang diaktivasi dengan cara panas sebesar $6,49 \%$. Untuk membuat arang aktif dengan kandungan abu yang baik adalah dengan cara kimia. Apabila dibandingkan dengan kadar abu arang aktif yang diperoleh dari pasar sebesar 18,30\%, maka kadar abu hasil penelitian masih lebih rendah (4,19-8,17\%).

\section{Kadar zat terbang}

Pada Tabel 1 terlihat bahwa kadar zat terbang arang aktif dari serbuk gergajian kayu $A$. mangium berkisar antara 1,93 - 8,81\%. Kadar zat terbang ini memenuhi Standar Nasional Indonesia (Anonim, 1995) karena kurang dari 25\%. Berdasarkan hasil uji sidik ragam (Tabel 2) ternyata cara aktivasi sangat mempengaruhi kadar zat terbang arang aktif yang dihasilkan. Kadar zat terbang tertinggi $(8,81 \%)$ terdapat pada arang serbuk gergajian kayu $A$. mangium yang diaktivasi dengan cara oksidasi. Kadar zat terbang terendah $(1,93 \%)$ terdapat pada arang serbuk gergajian kayu $A$. mangium yang diaktivasi dengan cara panas. Tingginya kadar zat terbang ini menunjukkan bahwa masih terdapatnya senyawa non-karbon yang menempel pada permukaan arang aktif terutama atom $\mathrm{H}$ yang terikat kuat pada atom $\mathrm{C}$ pada permukaan arang aktif dalam bentuk $\mathrm{C}\left(\mathrm{H}_{2}\right)$. 
Hasil uji-beda (Lampiran 1) menunjukkan bahwa cara aktivasi memberikan perbedaan yang nyata terhadap kadar zat terbang. seperti arang serbuk gergajian kayu $A$. mangium yang diaktivasi dengan cara kimiasebesar 5,07\% tidak menyebabkan perbedaan dengan arang serbuk gergajian kayu $A$. mangium yang diaktivasi dengan cara kombinasi kimia dan oksidasi sebesar 5,88\%. Hal ini berarti untuk membuat arang aktif yang memiliki kadar zat terbang yang rendah sebaiknya menggunakan cara panas. Apabila dibandingkan dengan kadar zat terbang yang berasal dari pasar sebesar 7,57\%, ternyata hanya kadar zat terbang yang dimiliki arang aktif yang diaktivasi dengan uap air $(8,81 \%)$ tidak jauh berbeda.

\section{Kadar karbon}

Pada Tabel 1 terlihat bahwa kadar karbon arang aktif dari serbuk gergajian kayu $A$. mangium berkisar antara 83,01 - 89,94\%. Angka kadar karbon ini memenuhi Standar Nasional Indonesia (Anonim, 1995) karena kadar karbonnya lebih 65\%. Berdasarkan hasil uji sidik ragam (Tabel 2) ternyata cara aktivasi tidak mempengaruhi kadar karbon arang aktif yang dihasilkan. Hal ini berarti untuk membuat arang aktif dengan kandungan karbon terbaik adalah dengan cara perlakuan panas.

Kadar karbon tertinggi $(89,94 \%)$ terdapat pada arang serbuk gergajian kayu $A$. mangium yang diaktivasi dengan cara panas. Kadar karbon terendah (83,01\%) terdapat pada arang serbuk gergajian kayu $A$. mangium yang diaktivasi dengan cara oksidasi. Rendahnya kadar karbon ini disebabkan selain dipengaruhi oleh kandungan zat terbang dan abu juga disebabkan oleh adanya reaksi pemurnian lebih lanjut antara atom karbon dengan atom nonkarbon seperti reaksi yang terjadi pada rendemen, sedangkan pada perlakuan panas reaksi pemurnian tidak terjadi sehingga kadar karbonnya relatif lebih besar. Apabila dibandingkan dengan kadar karbon yang berasal dari pasar sebesar 81,47\% maka kadar karbon hasil penelitian mutunya masih lebih baik (83,01-89,94\%).

\section{Daya serap terhadap benzena}

Pada Tabel 1 terlihat bahwa daya serap arang aktif dari serbuk gergajian kayu $A$. mangium terhadap benzena berkisar antara 9,08 - 15,28\%. Nilai ini tidak memenuhi Standar Nasional Indonesia (Anonim, 1995) karena daya serapnya kurang dari 25\%. Berdasarkan hasil uji sidik ragam (Tabel 2) ternyata cara aktivasi sangat mempengaruhi daya serap arang aktif terhadap benzena. Daya serap tertinggi $(15,28 \%)$ terdapat pada arang serbuk gergajian kayu $A$. mangium yang diaktivasi dengan cara oksidasi, sedangkan daya serap terendah $(9,08 \%)$ terdapat pada arang serbuk gergajian kayu $A$. mangium yang diaktivasi dengan cara panas. Rendahnya daya serap ini menunjukkan bahwa masih terdapatnya senyawa non karbon terutama atom $\mathrm{H}$ dan O yang menempel pada permukaan arang aktif sehingga permukaan arang aktifnya lebih bersifat non polar.

Hasil uji-beda (Lampiran 1) menunjukkan bahwa tidak semua perlakuan aktivasi memberikan perbedaan yang nyata terhadap daya serap benzena. Seperti arang serbuk gergajian kayu $A$. mangium yang diaktivasi dengan cara oksidasi memiliki daya serap yang tidak berbeda dengan arang serbuk gergajian kayu $A$. mangium yang diaktivasi dengan cara kombinasi fisika dan kimia. Untuk membuat arang aktif dengan daya serap yang baik sebaiknya menggunakan cara oksidasi. Apabila dibandingkan dengan daya serap benzena yang berasal dari pasar sebesar 19,15\% maka daya serap hasil penelitian masih lebih rendah $((9,08-15,28 \%)$. 


\section{Daya serap terhadap kloroform}

Pada Tabel 1 terlihat bahwa daya serap arang aktif dari serbuk gergajian kayu $A$. mangium terhadap kloroform berkisar antara 12,86 - 28,96\%. Angka daya serap terhadap klorofrom ini tidak memenuhi standar Departemen Kesehatan karena daya serapnya kurang dari 40\%. Berdasarkan hasil uji sidik ragam (Tabel 2) ternyata cara aktivasi sangat mempengaruhi daya serap arang aktif terhadap benzena. Daya serap tertinggi $(28,96 \%)$ terdapat pada arang serbuk gergajian kayu $A$. mangium yang diaktivasi dengan cara kombinasi oksidasi dan kimia. Daya serap terendah $(12,86 \%)$ terdapat pada arang serbuk gergajian kayu $A$. mangium yang diaktivasi dengan cara kimia. Rendahnya daya serap ini disebabkan oleh gugus $\mathrm{P}_{2} \mathrm{O}_{5}$ hasil dekomposisi H3PO4 yang menempel dan terikat pada permukaan arang aktif sehingga lebih bersifat polar.

Hasil uji-beda (Lampiran 1) menunjukkan bahwa tidak semua cara aktivasi memberikan perbedaan yang nyata terhadap daya serap kloroform. Seperti arang serbuk gergajian kayu $A$. mangium yang diaktivasi dengan cara panas menghasilkan daya serap sebesar 13,03\% yang tidak berbeda dengan arang serbuk gergajian kayu $A$. mangium yang diaktivasi dengan cara kimia sebesar $12,86 \%$. Untuk membuat arang aktif dengan daya serap yang baik sebaiknya menggunakan cara kombinasi oksidasi dan kimia. Apabila dibandingkan dengan daya serap kloroform yang berasal dari pasar sebesar $27,31 \%$ maka arang aktif pasar daya serapnya masih lebih baik.

\section{Daya serap terhadap formaldehida}

Pada Tabel 1 terlihat bahwa daya serap arang aktif dari serbuk gergajian kayu $A$. mangium terhadap formaldehida berkisar antara 8,8426,21\%. Berdasarkan hasil uji sidik ragam (Tabel 2) ternyata perlakuan cara aktivasi sangat mempengaruhi daya serap arang aktif terhadap formaldehida. Daya serap tertinggi $(26,21 \%)$ terdapat pada arang arang serbuk gergaji A.mangium yang diaktivasi dengan cara kombinasi oksidasi dan kimia. Daya serap terendah $(8,84 \%)$ terdapat pada arang serbuk gergajian kayu $A$. mangium yang diaktivasi dengan cara panas.

Hasil uji-beda (Lampiran 1) menunjukkan bahwa tidak semua cara aktivasi memberikan perbedaan yang nyata terhadap daya serap formaldehida. Seperti arang serbuk gergajian kayu A. mangium yang diaktivasi dengan cara uap air (26,05\%) tidak menghasilkan daya serap yang berbeda dengan arang serbuk gergajian kayu $A$. mangium yang diaktivasi dengan cara kombinasi oksidasi dan kimia (26,21\%). Apabila dibandingkan dengan daya serap formaldehida yang berasal dari pasar sebesar 28,73\% maka arang aktif pasar mutunya masih lebih baik.

\section{Daya serap terhadap yodium}

Pada Tabel 1 terlihat bahwa daya serap arang aktif dari serbuk gergajian kayu $A$. mangium terhadap yodium berkisar antara 453,53 - 960,23 mg/g. Dari angka ini yang memenuhi standar Indonesia (Anonim, 1995) adalah hanya arang aktif yang dibuat dengan cara oksidasi dan kombinasi antara cara kimia dan oksidasi karena daya serapnya lebih dari $750 \mathrm{mg} / \mathrm{g}$. Berdasarkan hasil uji sidik ragam (Tabel 2) ternyata cara aktivasi sangat mempengaruhi daya serap arang aktif terhadap yodium. Daya serap tertinggi (960,23 mg/g) terdapat pada arang serbuk gergajian kayu $A$. mangium yang diaktivasi dengan cara kombinasi oksidasi dan kimia. 
Daya serap terendah $(453,53 \mathrm{mg} / \mathrm{g})$ terdapat pada arang serbuk gergajian kayu $A$. mangium yang diaktivasi dengan cara panas. Rendahnya daya serap ini menunjukkan bahwa perlakuan panas pada suhu $800^{\circ} \mathrm{C}$ belum cukup untuk membuka pori-pori arang.

Hasil uji-beda (Lampiran 1) menunjukkan bahwa tidak semua cara aktivasi memberikan perbedaan yang nyata terhadap daya serap yodium. Seperti arang serbuk gergajian kayu $A$. mangium yang diaktivasi dengan cara oksidasi $(916,0 \mathrm{mg} / \mathrm{g})$ tidak menghasilkan daya serap yang berbeda dengan arang serbuk gergajian kayu $A$. mangium yang diaktivasi dengan cara kombinasi oksidasi dan kimia $(960,2 \mathrm{mg} / \mathrm{g})$. Untuk membuat arang aktif dengan daya serap yang baik sebaiknya menggunakan cara oksidasi. Apabila dibandingkan dengan daya serap yodium yang berasal dari pasar sebesar $626,33 \mathrm{mg} / \mathrm{g}$ maka arang aktif hasil penelitian mutunya masih lebih baik (453,53 - 960,23 mg/g).

\section{Daya serap terhadap metilen biru}

Guna mengetahui kemampuan arang aktif dari serbuk gergajian kayu $A$. mangium untuk menyerap larutan berwarna dan jumlah pori-pori arang aktif berdiameter $15 \AA$ dilakukan penetapan daya serap terhadap metilen biru (Tabel 1) yang hasilnya berkisar antara 63,7-135,0 $\mathrm{mg} / \mathrm{g}$. Tingginya nilai ini mengindikasikan bahwa senyawa hidro karbon yang terdapat pada permukaan arang yang diaktivasi telah banyak menjadi aktif, dan ikatan antara hidrogen dan karbon terlepas dengan sempurna sehingga semakin luas permukaan yang aktif.

Hasil uji sidik ragam (Tabel 2) menunjukkan bahwa daya serap arang aktif terhadap metilen biru sangat dipengaruhi oleh cara aktivasi. Daya serap tertinggi $(135,0 \mathrm{mg} / \mathrm{g})$ terdapat pada arang serbuk gergajian kayu $A$. mangium yang diaktivasi dengan cara kombinasi oksidasi dan kimia. Daya serap terendah $(63,7 \mathrm{mg} / \mathrm{g})$ terdapat pada arang serbuk gergajian kayu $A$. mangium yang diaktivasi dengan cara panas.

Hasil uji-beda (Lampiran 1) menunjukkan bahwa tidak semua cara aktivasi memberikan perbedaan yang nyata terhadap daya serap metilin biru. Seperti arang serbuk gergajian kayu $A$. mangium yang diaktivasi dengan cara panas $(63,7 \mathrm{mg} / \mathrm{g})$ tidak menghasilkan daya serap yang berbeda dengan arang serbuk gergajian kayu $A$. mangium yang diaktivasi dengan cara kimia (71,1 mg/g). Apabila dibandingkan dengan daya serap metilin biru yang berasal dari pasar sebesar $102,7 \mathrm{mg} / \mathrm{g}$ maka arang aktif hasil penelitian mutunya masih lebih baik (63,7-135,0 $\mathrm{mg} / \mathrm{g})$.

\section{B. Aplikasi Arang Aktif sebagai Reduktor Emisi Formaldehida Kayu Lapis}

\section{Kerapatan kayu lapis}

Salah satu sifat fisis kayu lapis yang mempengaruhi sifat mekanisnya adalah kerapatan kayu lapis. Nilai kerapatan kayu lapis yang diteliti berkisar antara 0,45-0,55 g/ $\mathrm{cm}^{3}$ (Tabel 2). Kerapatan terendah $\left(0,45 \mathrm{~g} / \mathrm{cm}^{3}\right)$ terdapat pada kayu lapis yang perekatnya diberi arang aktif yang dibuat dengan cara oksidasi gas dan kerapatan tertinggi $\left(0,55 \mathrm{~g} / \mathrm{cm}^{3}\right)$ dimiliki kayu lapis yang perekatnya diberi arang aktif yang dibuat dengan cara kombinasi oksidasi gas dan kimia. Perbedaan ini lebih disebabkan oleh kerapatan dari arang aktif itu sendiri, di mana arang serbuk gergajian kayu $A$. mangium yang diaktivasi dengan cara oksidasi gas kerapatannya lebih tinggi. Hasil uji sidik ragam (Tabel 2), menunjukkan bahwa kerapatan kayu lapis tidak dipengaruhi oleh perlakuan yang diberikan. 
Tabel 2. Hasil uji sidik ragam kualitas arang aktif dan kayu lapis setelah ditambah arang aktif

Table 2. Analysis of variance on activated charcoal and plywood quality after addition of active charcoal

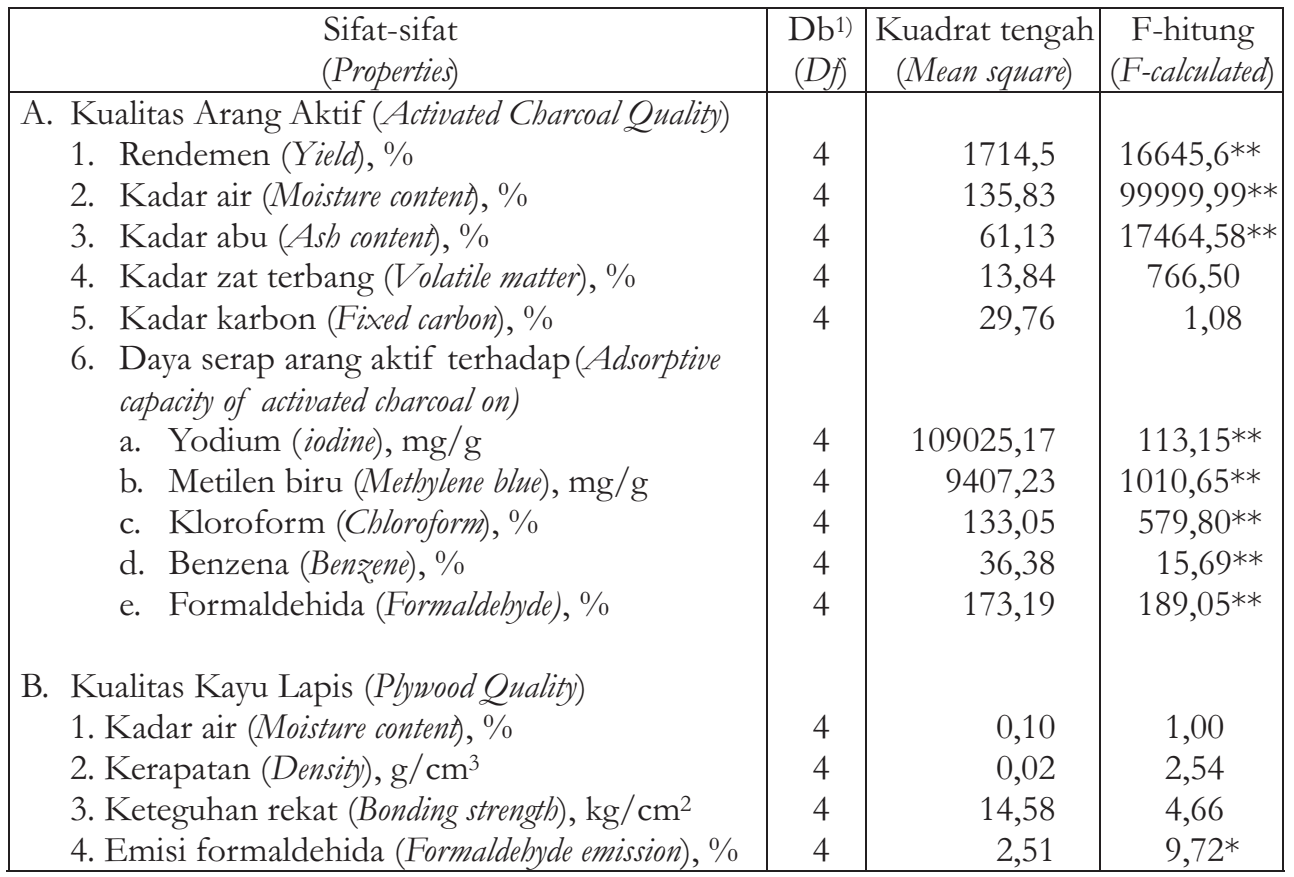

Keterangan (Remarks) : * = Nyata (Significant); ** = Sangat nyata (Highly siginficant); Db: Derajat bebas (Degree of freedom)

\section{Kadar air kayu lapis}

Kadar air kayu lapis berkisar antara 12,0-12,5\% (Tabel 3), dan semuanya memenuhi persyaratan Standar Nasional Indonesia karena nilainya kurang dari 14\% (Anonim, 1992). Kadar air terendah $(12,0 \%)$ terdapat pada kayu lapis yang perekatnya diberi arang aktif yang dibuat dengan cara pemanasan dan kadar air tertinggi (12,5\%) diperoleh kayu lapis yang perekatnya diberi arang aktif yang dibuat dengan cara oksidasi gas. Tingginya kadar air kayu lapis ini lebih menunjukkan adanya uap air yang terperangkap di dalam kisi heksagonal arang aktif pada waktu proses aktivasi. Seperti halnya kerapatan, menurut hasil uji sidik ragam (Tabel 2) diketahui bahwa kadar air kayu lapis ini tidak dipengaruhi oleh perlakuan yang diberikan.

\section{Emisi formaldehida kayu lapis}

Emisi formaldehida kayu lapis yang perekatnya diberi arang aktif 5\% berkisar antara 15,36 - 16,70 ppm (Tabel 3). Nilai emisi formaldehida yang dihasilkan semuanya tidak ada yang memenuhi persyaratan Standar Nasional Indonesia (Anonim, 1992) karena nilainya 
Tabel 3. Kualitas kayu lapis

Table 3. Plywood quality

\begin{tabular}{|c|c|c|c|c|c|c|}
\hline \multirow{2}{*}{ Kualitas (Quality) } & \multicolumn{6}{|c|}{ Perlakuan (Treatment) } \\
\hline & $a_{1}$ & $\mathrm{a}_{2}$ & $a_{3}$ & $\mathrm{a}_{4}$ & $\mathrm{a}_{5}$ & $a_{6}$ \\
\hline 1. Kadar air (Moisture content), $\%$ & 12,0 & 12,5 & 12,0 & 12,0 & 12,0 & 12,3 \\
\hline 2. Kerapatan (Density), $\mathrm{g} / \mathrm{cm}^{3}$ & 0,54 & 0,45 & 0,55 & 0,49 & 0,51 & 0,47 \\
\hline $\begin{array}{l}\text { 3. Keteguhan rekat (Bonding strength), } \\
\mathrm{kg} / \mathrm{cm}^{2}\end{array}$ & 16,69 & 10,43 & 14,81 & 10,61 & 14,86 & 13,75 \\
\hline $\begin{array}{l}\text { 4. Emisi formaldehida (Formaldebyde } \\
\text { emission), ppm }\end{array}$ & 15,92 & 15,65 & 16,70 & 15,36 & 13,17 & 16,48 \\
\hline
\end{tabular}

Keterangan (Remarks) $:$ a1 = Perlakuan dengan bahan kimia (Chemicaltreatment); a2 = Perlakuan dengan fisika (Physical treatment); a3 = Perlakuan dengan bahan kimia dan uap air (Combination of chemical and physical); a4 = Perlakuan dengan panas (Heat treatment); a5 = Arang aktif pasaran (Commercial activated charcoa); a6 = Kayu lapis tanpa arang aktif (Plywood without activated charcoal).

lebih dari 0,5 ppm. Emisi formaldehida terendah (15,36 ppm) terdapat pada kayu lapis yang perekatnya diberi arang aktif yang dibuat dengan cara pemanasan dan emisi formaldehida tertinggi $(16,70 \mathrm{ppm})$ diperoleh kayu lapis yang perekatnya ditambah arang aktif yang dibuat dengan cara kombinasi oksidasi gas dan kimia. Tingginya emisi formaldehida tersebut disebabkan oleh besarnya kadar formaldehida bebas dalam perekat kayu lapis yang digunakan (Christensen et al., 1981).

Hasil ini mengindikasikan bahwa jumlah arang aktif yang ditambahkan pada perekat kayu lapis tidak mencukupi untuk mengadsorpsi seluruh formaldehida dalam kayu lapis. Namun demikian menurut hasil uji sidik ragam (Tabel 2) menunjukkan bahwa penurunan emisi formaldehida sangat dipengaruhi oleh perlakuan yang diterapkan, dengan perkataan lain permakaian arang aktif dalam ramuan perekat mampu menurunkan emisi formaldehida kayu lapis dengan sangat nyata.

\section{Keteguhan rekat kayu lapis}

Keteguhan rekat kayu lapis yang perekatnya diberi arang aktif berkisar antara 10,61$16,69 \mathrm{~kg} / \mathrm{cm}^{2}$ (Tabel 3) dengan nilai tertinggi $\left(16,69 \mathrm{~kg} / \mathrm{cm}^{2}\right)$ diperoleh pada kayu lapis yang perekatnya ditambah arang aktif yang menggunakan proses kimia dan yang terendah $\left(10,61 \mathrm{~kg} / \mathrm{cm}^{2}\right)$ terdapat pada kayu lapis yang perekatnya diberi arang aktif yang dibuat dengan cara dipanaskan (tanpa diaktivasi). Nilai kisaran keteguhan rekat kayu lapis tersebut memenuhi persyaratan Standar Nasional Indonesia (Anonim, 1992) karena nilainya $>7 \mathrm{~kg} /$ $\mathrm{cm}^{2}$ (Anonim, 1992). Hal ini menunjukkan bahwa arang aktif yang ditambahkan ke dalam ramuan perekat kayu lapis selain dapat menurunkan emisi formaldehida juga dapat dapat berfungsi sebagai bahan pengisi (filler).

Berdasarkan sidik ragam (Tabel 2) diketahui bahwa penambahan arang aktif pada perekat kayu lapis tidak berpengaruh nyata terhadap keteguhan rekat kayu lapis. 


\section{KESIMPULAN}

Kualitas arang aktif terbaik dan memenuhi persyaratan kualitas arang aktif yang ditetapkan SNI terdapat pada arang serbuk kayu mangium yang diaktivasi dengan cara kombinasi oksidasi gas dan kimia dengan rendemen arang aktif sebesar 53\%, kadar air 4,33\%, kadar abu 8,17\%, kadar zat terbang 5,88\%, kadar karbon terikat $83,77 \%$, daya serap terhadap yodium sebesar $960,2 \mathrm{mg} / \mathrm{g}$, metilien biru $135,0 \mathrm{mg} / \mathrm{g}$, benzena $14,59 \%$, kloroform $28,96 \%$ dan daya serap terhadap formaldehida sebesar $26,21 \%$.

Penambahan arang aktif serbuk gergajian kayu $A$. mangium pada perekat kayu lapis mampu menurunkan emisi formaldehida dari kayu lapis. Emisi formaldehida dari kayu lapis yang tidak ditambahkan arang aktif (16,48 ppm) berkurang menjadi 15,36 ppm setelah penambahan arang aktif sebanyak 5\% dalam ramuan perekatnya, tanpa mempengaruhi keteguhan rekat kayu lapis tersebut. Namun demikian nilai emisi formaldehida ini belum memenuhi persyaratan kualitas kayu lapis yang ditetapkan SNI.

\section{DAFTAR PUSTAKA}

Anonim. 1982. The Test method for evaporated amount of formaldehyde in Japanese Agricultural Standard for ordinary plywood, Plywood for special use, and flooring plywood. Japanese Standard Association, Tokyo.

1992 Mutu kayu lapis penggunaan umum. Standar Nasional Indonesia. SNI.012704-1992. Badan Standardisasi Nasional, Jakarta.

. 1995. Arang aktif teknis. Standar Nasional Indonesia. SNI 06-3730-1995.Badan Standardisasi Nasional, Jakarta.

Asano, N., J. Nishimura., K. Nishimiya., T. Hata, Y. Imamura., S. Ishihara, and B. Tomita. 1999. Formaldehyde reduction in indoor environment by wood charcoals. Wood Reasearch No 86. p: 7-8. Tokyo, Japan.

Baker, F.S., Miller, C.E., Repik, A.J and E.D Tollens. 1997. Activated carbon. Encyclopedia of separation technology. John Wiley and Sons, New York.

Christensen R.P, Robitscheck and J. Stone. 1981. Formaldehyde emission from particleboard. Holz ails Roh Und. Werkstoff. Germany.

Solovyov, L.A., A.N. Shmakov., V.I. Zaikovski., S.H. Joo, and R. Ryoo. 2002. Detailed structure of the hexagonally packed mesostructured carbon material CMK-3. Carbon $40: 2477-2481$. Elsevier, UK. 
Lampiran 1. Hasil uji BNJ sifat arang aktif dari serbuk gergaji kayu A. mangium Appendix 1. Test result of HSD on activated charcoal properties of A.mangium sarwdust

\begin{tabular}{|c|c|c|c|c|c|}
\hline $\begin{array}{ll}\text { No. } & \text { Sifat-sifat } \\
& \text { (Properties) }\end{array}$ & $\begin{array}{l}\text { Perlakuan } \\
\text { (Treatment) }\end{array}$ & \multicolumn{4}{|c|}{$\begin{array}{l}\text { Nilai rata-rata yang dibandingkan } \\
\text { (Comparison of mean value) }\end{array}$} \\
\hline 1. Rendemen (Yield), \% & A & $\begin{array}{c}a 2 \\
46,25\end{array}$ & $\begin{array}{c}\text { a1 } \\
48,00\end{array}$ & $\begin{array}{c}\text { a3 } \\
53,00\end{array}$ & $\begin{array}{c}\text { a4 } \\
81,50\end{array}$ \\
\hline $\begin{array}{l}\text { 2. Kadar air } \\
\text { (Moisture content), \% }\end{array}$ & A & $\begin{array}{c}\text { a1 } \\
2,89\end{array}$ & $\begin{array}{c}\text { a4 } \\
3,25\end{array}$ & $\begin{array}{c}\mathrm{a} 2 \\
3,28\end{array}$ & $\begin{array}{c}\text { a3 } \\
4,33\end{array}$ \\
\hline 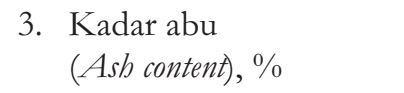 & A & $\begin{array}{c}\text { a1 } \\
4,19\end{array}$ & $\begin{array}{c}\text { a4 } \\
6,49 \\
\end{array}$ & $\begin{array}{r}a 2 \\
6,55 \\
\end{array}$ & $\begin{array}{c}\text { a3 } \\
8,17\end{array}$ \\
\hline $\begin{array}{l}\text { 4. Kadar zat terbang } \\
\text { (Volatile matter), } \%\end{array}$ & A & $\begin{array}{c}\text { a4 } \\
1,93\end{array}$ & $\begin{array}{c}\text { a1 } \\
5,07\end{array}$ & $\begin{array}{c}\text { a3 } \\
5,88\end{array}$ & $\begin{array}{c}\mathrm{a} 2 \\
8,81\end{array}$ \\
\hline $\begin{array}{l}\text { 5. Kadar karbon } \\
\text { (Fixed carbon), \% }\end{array}$ & A & $\begin{array}{c}\mathrm{a} 2 \\
83,01\end{array}$ & $\begin{array}{c}\text { a3 } \\
83,77 \\
\end{array}$ & $\begin{array}{c}\text { a1 } \\
89,29\end{array}$ & $\begin{array}{c}\mathrm{a} 4 \\
89,94 \\
\end{array}$ \\
\hline $\begin{array}{l}\text { 6. Daya serap yodium } \\
\text { (Adsorption capacity of } \\
\text { iodine }), \mathrm{mg} / \mathrm{g}\end{array}$ & A & $\begin{array}{c}\text { a4 } \\
453,5\end{array}$ & $\begin{array}{c}\text { a1 } \\
505,69\end{array}$ & $\begin{array}{c}a 2 \\
6,09\end{array}$ & $\begin{array}{c}\text { a3 } \\
60,2\end{array}$ \\
\hline $\begin{array}{l}\text { 7. Daya serap metilin biru } \\
\text { (Adsorptive capacity of } \\
\text { methyline blue), } \mathrm{mg} / \mathrm{g}\end{array}$ & A & $\begin{array}{c}\mathrm{a} 4 \\
63,7 \\
\end{array}$ & $\begin{array}{c}\text { a1 } \\
71,1\end{array}$ & $\begin{array}{c}\mathrm{a} 2 \\
122,8\end{array}$ & $\begin{array}{c}\text { a3 } \\
135,0\end{array}$ \\
\hline $\begin{array}{l}\text { 8. Daya serap benzena } \\
\text { (Adsorptive capacity of } \\
\text { benzene), } \%\end{array}$ & A & $\begin{array}{c}\text { a4 } \\
9,08 \\
\end{array}$ & $\begin{array}{c}\text { a1 } \\
9,20 \\
\end{array}$ & $\begin{array}{c}\text { a3 } \\
14,59\end{array}$ & $\begin{array}{c}a 2 \\
15,28 \\
\end{array}$ \\
\hline $\begin{array}{l}\text { 9. Daya serap kloroform } \\
\text { (Adsorptive capacity of } \\
\text { chloroform), } \%\end{array}$ & A & $\begin{array}{c}\text { a1 } \\
12,86\end{array}$ & $\begin{array}{c}\text { a4 } \\
13,03 \\
\end{array}$ & $\begin{array}{c}\mathrm{a} 2 \\
27,05\end{array}$ & $\begin{array}{c}\text { a3 } \\
28,96\end{array}$ \\
\hline $\begin{array}{l}\text { 10. Daya serap } \\
\text { formaldehida } \\
\text { (Adsorptive capacity of } \\
\text { formaldebyde), } \%\end{array}$ & $\mathrm{~A}$ & $\begin{array}{c}\text { a4 } \\
8,84\end{array}$ & $\begin{array}{c}\text { a1 } \\
11,57\end{array}$ & $\begin{array}{c}\mathrm{a} 2 \\
26,05\end{array}$ & $\begin{array}{c}a 3 \\
26,21\end{array}$ \\
\hline
\end{tabular}

Keterangan (Remarks) $:$ a1 = Perlakuan dengan bahan kimia (Chemical treatment); a2 = Perlakuan dengan fisika (Physical treatment); a3 = Perlakuan dengan bahan kimia dan uap air (Combination treatment of chemical and physical); 44 = Perlakuan dengan panas (Heat treatment); $=$ Tidak nyata (Non significant) 